\title{
Calibration of Rock Cutting Numerical Model based on Monitoring Data
}

(Penentukuran Model Berangka bagi Pemotongan Batu berdasarkan Data Pemantauan)

\author{
Vedran PaVlic, Mario Bacic* \& Meho Sasa KovaceViC
}

\begin{abstract}
Prediction of the deformation increment and the final displacement of the rock cutting is a challenging task. Many ambiguities linked with unpredictable nature or rock mass make it difficult to apply the adequate contingency measures. Implementation of common approach, which includes modelling of discontinuity effects with estimated reduction of rock mass strength and modulus of elasticity, usually does not yield satisfactory results. Therefore, a calibration of FEM based numerical model was made by conducting parametric analysis which feeds upon data obtained from extensive on-site monitoring system. A step forward was made in description of numerical parameters of karst discontinuities through consideration of monitoring results, as well as excavation procedures, position, inclination and length of discontinuities and PDC (project design change).
\end{abstract}

Keywords: Discontinuities; karst; numerical modelling; observational method; rock mass

\section{ABSTRAK}

Ramalan kenaikan canggaan dan sesaran akhir pemotongan batu adalah satu tugas yang mencabar. Banyak kesamaran yang dikaitkan dengan sifat yang tidak dapat diramalkan atau jisim batu menyukarkan untuk menggunakan langkah kontingensi yang mencukupi. Pelaksanaan pendekatan biasa yang merangkumi pemodelan kesan ketakselanjaran dengan anggaran pengurangan kekuatan jisim batu dan modulus keanjalan, kebiasaannya tidak memberikan keputusan yang memuaskan. Oleh itu, penentukuran model berangka FEM dibuat dengan menjalankan analisis parametrik yang menggunakan data yang diperoleh daripada sistem pemantauan ekstensif di tapak. Satu penambahbaikan telah dibuat dalam penerangan parameter berangka ketakselanjaran karst dengan mempertimbangkan keputusan pemantauan serta prosedur pengorekan, kedudukan, kecenderungan dan panjang ketakselanjaran dan PDC (perubahan reka bentuk projek).

Kata kunci: Jisim batu; kaedah pemerapan; karst; ketakselanjaran; pemodelan berangka

\section{INTRODUCTION}

Rock mass consists of an intact rock (an aggregate of binder-bound particles) that has been disrupted by discontinuities (bedding planes, fractures, faults), i.e. blocks system, which affect the rock mass characteristics (Chen et al. 2019). The discontinuity effect is nonlinear, anisotropic and dominant in the environment of low stress (slopes, surface excavations). In the numerical model, discontinuities (joints) are included in three ways (Latha \& Garaga 2012). The first is by modelling the rock mass as a continuum, e.g. Finite Element Method (FEM), applying gradual reduction of the rock mass strength parameters technique and using of the special splitting/joining elements. The second way is to model the rock mass as a discontinuum, e.g. DEM (Discrete Element Method) and to conduct the discontinuous deformation analysis. The third way is to combine multiple methods, e.g. manifold method, finite-discrete element method. From the designer's point of view, a first approach is most favored due to simple fact that it requires an input data which is least difficult to obtain in comparison with other two modelling methods. The term 'least difficult' is appropriate since credible representation of discontinuous rock mass is not an easy task due to many ambiguities linked with its unpredictable nature. However, much advance has been made in field of DEM modelling for rock slope stability analysis, by implementing novel techniques such as photogrammetry and 3D mapping system (Bonilla-Sierra et al. 2015) or different types of laser scanning (Sturzeneger et al. 2009).

The implementation of the observation methods (Bjureland et al. 2017), comes to fore especially in rock related projects. The monitoring is included in Eurocode 7 as important aspect of design during construction -'monitoring shall be assessed at appropriate stages and the planned contingency actions shall be put into operation if the limits of behavior are exceeded'. Many research was dealing with numerical modelling techniques for analysis in rock engineering (Jing et al. 2002; Tang et al. 2017), however, combination of monitoring and modelling techniques usually yields a better understanding of behavior of geotechnical structures in rock mass (Huang et al. 2009). Therefore, this paper considers the possibilities of utilizing monitoring data for the calibration of discontinuity properties of numerical model, where the considered case study will be Zagrad B complex (Pavlic 2014) as one of most challenging construction pit project in 
karstic region of Croatia. The instabilities linked with karst can significantly affect the surrounding areas (Mohd Razib et al. 2018). The construction method includes excavation in steps, protection of the slope and measurement results analysis based on which the numerical model is calibrated. Following the calibration, the model is used to predict the increment of deformation (deformation after removing a certain, smaller rock mass volume) and to determine the threshold for the implementation of contingency measures (stressing of cable anchors, installing additional ground anchors, backfilling). In order to predict a more realistic mechanical behavior of the rock mass, blocks and primary (activated) discontinuities are decoupled and separately numerically modeled. The block may be an intact rock or an EG (engineering geological) block, i.e. an intact rock streaked with a secondary discontinuity set. The above procedure is similar to the two-scale concept (Lin $\& \mathrm{Ku}$ 2006). Mechanical properties of intact rocks are determined through laboratory testing, and the properties of the EG block are determined by the synthesis of results obtained through laboratory testing, field classification and geophysical survey. Mechanical properties of discontinuities (stiffness, strength) depend on their geometric characteristics (roughness, infilling, length and orientation). Determination of these characteristics on the field is a challenging task, and there is little information on discontinuity properties determination for the karstic rock mass in the literature. As a consequence, designers usually rely on estimation procedures, which generally do not yield credible deformation values and trends.

\section{STUDY AREA}

'Zagrad B' complex construction pit was constructed in the highly urbanized center of Rijeka, Croatia, between the railway line from the south side, 'Zagrad A' complex on the left, and residential buildings on the northern side. The approximate dimensions of the construction pit are 80 $\times 40 \times 20 \mathrm{~m}($ Figure 1$)$.

The location of the construction pit is characterized by a terrain covered with karst. Below the karst lies the dolomite limestone of the Cenomanian-Turonian stage of the Upper Cretaceous epoch. The limestone is crystalline, solid with a pronounced karstification.

\section{ESTABLISHED MONITORING SCHEME}

Prior to construction, an extensive system of measurements and observations was established and monitoring activities were conducted during and after the construction. The monitoring scheme consists of the following:

Creating $E G$ profiles, which consist of intact rock streaked with a secondary discontinuity sets, by mapping the slope immediately after excavation; Measuring angles of object rotation next to the cut with a tiltmeter $(K)$; Measuring spatial displacements with a survey network $(R)$; Measuring rock mass displacement with a vertical inclinometer and sliding micrometer (VI); Measuring rock mass displacements with a horizontally placed sliding micrometer $(H D)$; and Measuring force in the cable anchors with a load cell $(L C)$.

Successful assessment and optimization of the design stabilization solution was carried out on five CPS (control profile), i.e. five two-dimensional numerical models. Each $C P$ includes a group of measuring equipment (Table 1). By comparing the data of different measuring instruments, potential measuring errors can be ruled out.

TABLE 1. List of CPS and measuring equipment

\begin{tabular}{ccl}
\hline mark & slope & built-in measuring equipment \\
\hline$C P 1$ & east & $V I 1 / H D 11$ \\
$C P 2$ & north & $V I 2 / H D 21 / H D 22 / K 2 / L C 3 \# / R \#$ \\
$C P 3$ & north & $V I 3 / H D 31 / H D 32 / K 3 / L C 2 \# / R \#$ \\
$C P 4$ & north & $V I 4 / H D 41 / H D 42 / L C 1 \# / R \#$ \\
$C P 5$ & west & $H D 81 / H D 82 / K 5 / R \#$ \\
\hline
\end{tabular}

ENGINEERING-GEOLOGICAL FEATURES OF THE SITE

Rock mass classification Geotechnical classification of the rock mass was performed according to the RMR (Rock Mass Rating) classification (Bieniawski 1989), which is used in the engineering practice together with the GSI (Geological Strength Index) classification (Marinos \& Hoek 2000). The GSI classification represents a simplified classification
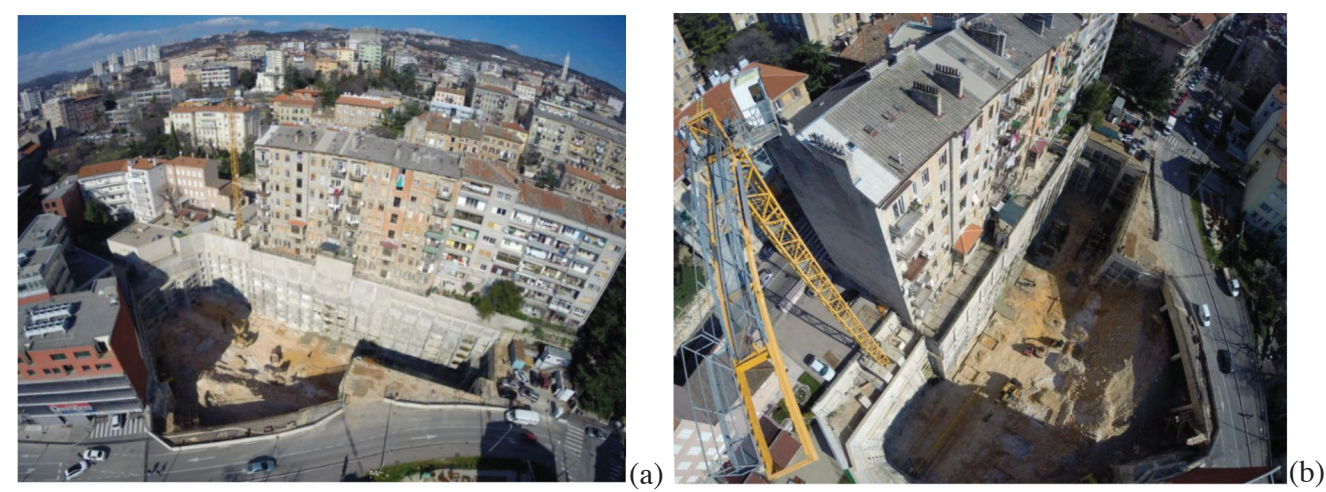

FIGURE 1. Photographs of the construction pit: (a) north-west direction (b) north-east direction (Frka 2014) 
system based on the assessment of lithology, structure and surface conditions of rock mass discontinuities and it is determined by visual examination of rock mass visible in cuttings and in surface excavations.

The classifications are linked by (1).

$$
R M R=G S I-5
$$

Parameters required to determine the rock mass quality, e.g. UCS, spacing, orientation and condition of the fractures, groundwater conditions, $R Q D$ (Rock Quality Designation), were determined by means of exploratory boreholes and outcrops near the construction pit. The drilling-based parameters were used for the initial numerical model.

During the excavation of the construction pit, $E G$ mapping of the slope was made for each excavation step, i.e. micro location. At the macro level, two EG blocks were isolated, i.e. two $E G$ middles: the upper wear layer and base rock (Vuic et al. 2014) with belonging propagation range of longitudinal waves $\left(v_{p}\right)$ (Table 2 ). The characteristics of the rock mass determined during the excavation of the first stages represent the basis for creating a more realistic numerical model.

Rock mass strength criterion In order to model the behavior of the rock mass, the Hoek-Brown's strength criterion was used (Hoek et al. 2002). The criterion requires the determination of the input parameters: uniaxial compression strength $\sigma_{c i}$, the coefficient dependent on the lithological composition of the intact rock $m_{i}$ and the coefficient dependent on the wear of the rock mass $D$.

The values of the $\sigma_{c i}$ parameter obtained by the means of laboratory testing are between 91 and 152 $\mathrm{MPa}$, the values of the $m_{i}$ parameter for the carbonates are between 6 and 15 and the values of the $D$ parameter are between 0 for the mechanical excavation in steps and 1 for the negative impact of construction on the site of the construction pit.

The Hoek-Brown's criterion provides good results to the peak strength of the rock mass without any significant discontinuities. After crossing the peak, it is necessary to determine the residual values of the criterion parameters in order to simulate the behavior of the rock mass ranging from ductile to brittle. So far, the residual criterion parameters have not been successfully determined and described, and thus the behavior of the rock mass after passing the peak remained only a discussion. The flaw of the criterion is that it does not separate the intact rock and discontinuities, and it tries to simulate a complex system as a homogeneous whole.

Determination of rock mass deformability parameters Deformability of the rock mass depends on the rock mass karstification, compressibility of the fractures and the material between the fractures. Due to anisotropy and a large number of discontinuities (different inclination, position, length), it is not possible to explicitly determine the modulus of deformability, i.e. the modulus of elasticity. For determining the moduli, empirical methods based on rock mass classification, geophysical tests, combination of the discussed methods and the results of the numerical back analyses were used.

From the available terms for determining rock mass deformability based on the rock mass classification, (2) was considered. This equation (Hoek \& Diederichs 2006) is based on a larger number of back analyses, which makes it more accurate than other empirical methods based on the classification. The tangent intact rock modulus of elasticity $\left(E_{i}\right)$ is used as an auxiliary value when determining the rock mass modulus of elasticity $\left(E_{m}\right)$. The obtained $E_{i}$ values range from 47 to $56 \mathrm{GPa}$ (the value of $50 \mathrm{GPa}$ was selected).

$$
E_{m}=E_{i}\left(0.02+\frac{1-D / 2}{1+e^{((60+15 D-G S I) / 11)}}\right)
$$

Deformability of the rock mass can be determined by the means of geophysical methods which are used to obtain the velocities of longitudinal and shear waves. The velocity of longitudinal waves can in some instances be determined in laboratory (He et al. 2017), but it is usually more reliable to obtain it in in-situ conditions. For urban environments, refraction microtremor is used, which utilize environmental noise as a source of excitation as opposed to other methods, thus exploiting the urban environment that presents a problem in other methods (Louie 2001).

Due to the dynamic nature of seismic waves, the obtained constants are called dynamic. The dynamic modulus of elasticity $\left(E_{d y n}\right)$ represents the stiffness of the rock mass at small deformations. Seismic tests cause deformations of the order of $0.0001 \%$, which is

TABLE 2. Rock mass classification

\begin{tabular}{ccccc}
\hline EG block & $R M R$ & $G S I$ & $v_{p}$ & Rock mass description \\
\hline I & 40 & 35 & $1800-3500 \mathrm{~m} / \mathrm{s}$ & $\begin{array}{l}\text { extremely karstified and fractured; spacing between fractures is between } 0.06 \\
\text { and } 0.2 \text { meters; aperture of the fracture walls is larger than } 1 \mathrm{~mm} \text {; infilling of } \\
\text { the fractures is argillaceous; fracture walls are very worn }\end{array}$ \\
II & 56 & 51 & $3500-5000 \mathrm{~m} / \mathrm{s}$ & poorly karstified and fractured; fracture systems have larger spacing \\
\hline
\end{tabular}


significantly less than the deformations caused by the construction of the structures in the rock.

By reducing $E_{d y n}$ it is possible to obtain a static modulus of elasticity corresponding to the deformation of the rock mass of 0.01 to $0.1 \%$ (characteristics for construction of the structures in the rock). In the previous research (Kujundzic \& Grujic 1966), dynamic and static modulus of elasticity are linked by (3).

$$
E_{m}=\frac{E_{d y n}}{5.3-\left(E_{d y n} / 200000\right)}
$$

Jurić Kaćunić et al. (2011) developed a novel approach for the determination of stiffness characteristics of karst, where (4) is proposed. This term links laboratory and geophysical tests using the $I K_{s}$ (rock mass stiffness index), which is the ratio of the measured propagation rate of longitudinal waves in the in-situ rock mass and in the laboratory sample, the modified GSI classification adapted to the characteristics of karst in Croatia (Pollak 2007), and the in-situ measured propagation velocities of rock mass longitudinal waves $\left(v_{p}\right)$.

$$
E_{m}=I K_{s} \times G S I^{2} \times v_{p}^{2}
$$

The GSI classification is performed by evaluating two basic rock mass characteristics, blockiness and discontinuity characteristics, which result in the index indicator, largely dependent on the basic geological features of the rocks. Jurić Kaćunić et al. (2011) confirmed the linear relationship between the GSI classification results and the propagation velocities of longitudinal waves. Given that the stiffness is shown to be proportional to the square of the velocity of propagation of the longitudinal waves, and that the velocity of propagation of the longitudinal waves is linearly proportional to the results of the GSI classification, it is mathematically clear that the stiffness is proportional to the square of the results of the GSI classification.

After the construction of the Zagrad A construction pit (adjacent pit), due to the large difference between the predicted and measured displacements, back analyses were performed. Gradual reduction of the initial modulus of elasticity (determined by the classification methods) adjusted the predicted deformations and measured final cut deformations (Arbanas 2003). The results of the back analyses are the reduced moduli of elasticity and the Poisson coefficient $(v)$ ranging from $127 \mathrm{MPa}$ for EG block I to 449 for EG block II.

Comparison of the moduli obtained by different methods, Figure 2 shows that the values of the moduli obtained on the basis of the back analysis from the adjacent location were the lowest. The reason is the fact that the rock mass was modeled as a continuum. The largest values of the moduli were obtained by the method based on the rock mass classification. The problem is that this method uses a database (required for prediction) that is not suitable for the karst region.

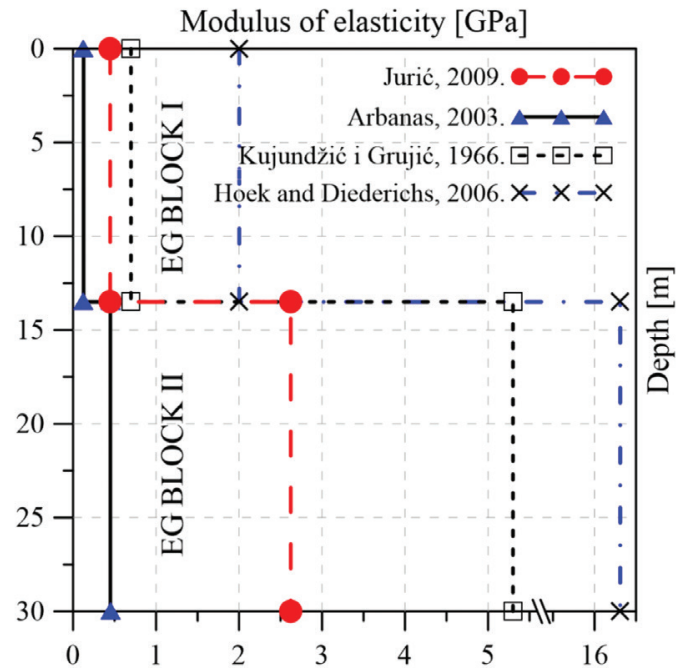

FIGURE 2. Comparison of the modulus of elasticity values

But why is not the intact rock modulus of elasticity used in a numerical simulation that takes into account discontinuities? The main discontinuity systems are mapped, and only the activated discontinuities are modeled. Rock characteristics between primary discontinuities, i.e. blocks, were determined by the means of the empirical method (Jurić Kaćunić et al. 2011). Due to their high wear, it is not possible to take representative sample (fractures, fracture infillings) (Figure 4). In the case of better rock quality (blocks without fractures, fracture infillings), block characteristics could be determined based on laboratory testing of representative samples.

\section{CONSTRUCTION PIT STRUCTURAL ELEMENTS}

Ground anchors The most important parameter for ground anchor modelling is the prestressing force, which in combination with the grillage construction, represents a 'membrane with braces' placed over the slope face. Changing the other parameters shows a limited impact on the cut behavior because the activated forces in the ground anchor do not reach its bearing capacity. The bearing capacity of the ground anchors has been tested by Tomac (2012), and the values of the parameters are given in Table 3 . In the analysis of the rock mass behavior, two ground anchor models were used.

The first type of ground anchor is a rock bolt model (Fully Bonded Bolt). The bolt is divided into segments depending on the location of the bolt intersection with the network of finite elements. The bolt segments appear unlinked to each other, and the mutual influence is indirect through their impact on the rock mass. The longitudinal force along the bolt is determined by the elongation of the length of the bolt segment, and the strains formed in the bolts are proportional to the amount of the sustained deformation.

Another type of ground anchor is a cable anchor model (Tieback) where the cable anchor consists of a 
TABLE 3. Input parameters for the ground anchor model and grillage structure

\begin{tabular}{ccccccc}
\hline anchor type & modulus of elasticity & diameter & bearing capacity & raster & prestressing & parameter value \\
\hline $\begin{array}{c}\text { rock bolt } \\
\text { cable anchor }\end{array}$ & $200 \mathrm{GPa}$ & $32.0 \mathrm{~mm}$ & $215 \mathrm{kN}$ & $3.7 \mathrm{~m}$ & $65 \mathrm{kN}$ & constant \\
variable
\end{tabular}

tendon free section and a tendon bond section that are sequentially connected. The free section represents a continuous tensile element which does not take over bending moments, the pressure and shear force, but it transmits the longitudinal force introduced between the anchor head and the tendon bond section. The tendon bond section takes over the longitudinal force and moves it in the form of the shear force to the rock mass.

Reinforced concrete grillage construction Reinforced concrete grillage construction is presented as an elastic layer applied to the slope face after excavation, i.e. as a reinforced membrane that closes the 'laboratory' sample. The sample in this case represents a karstified rock mass. Comparison of the results of the numerical FEM model and the laboratory experiment in previous research (Shen et al. 1978) shows that it is possible to minimize the influence of boundary conditions (elements) in the numerical model in such a way that the sample and membrane have similar elastic properties.

The rock mass is divided into two $E G$ blocks. The $E G$ block I has a smaller modulus of elasticity (smaller modulus $\rightarrow$ larger karstification $\rightarrow$ larger impact of the membrane) and according to that the modulus of elasticity of the grillage construction was selected (Table 3 ). The influence of the grillage construction is important due to the proximity of the slope face and the vertical inclinometer (1.7 $\mathrm{m}$ spacing) based on which the discontinuity parameters were calibrated.

\section{CALIBRATION OF THE DISCONTINUITIES PARAMETERS}

Description of the rock mass failure mechanism depends on the observation scale. Discontinuity failure mechanism is a combination of dilatation, crushing the irregularities on the contact surface (asperities), and the size of the contact surface. The mode of the discontinuity failure depends on the depth, i.e. pressure in the rock mass. At a low pressure, failure, i.e. sliding, is characterized by the absence of the damage to the asperities, as well as by great dilatation and friction values. At high pressures, failure is a combination of plastic deformation of the asperities (cohesion component) and slip (friction component). Parameters are determined by in situ measurements, e.g. visual roughness comparisons JRC (Joint Roughness Coefficient), determination of the discontinuity strength using the Schmidt hammer JCS (Joint Wall Compressive Strength). The behavior of the rock mass, and therefore the failure mechanisms (separation, sliding and rotation of blocks) depend on the type and intensity of the external load, boundary conditions, characteristics of the intact rock, discontinuity network and discontinuity parameters. Among mentioned, determination of discontinuity parameters with field-based procedures, which depend on the field situation, is most challenging task. Once the initial parameters are calibrated, another problem occurs related to the determination of the reduction factor, i.e. determination of the residual values of the discontinuity parameters.

\section{NUMERICAL REPRESENTATION OF DISCONTINUITIES}

In order to model the rock mass successfully, it is necessary to separate the influence of the blocks and the primary discontinuities. There are two ways of modelling the rock mass: Indirectly (represented by means of constituent relationships; material is the idealization of the continuum; averaged values are used) and directly (represented by the formation and monitoring of micro fractures; material is the idealization of a set of discrete elements and mechanical spring models, sliders; average and individual values are used).

The FEM method is based on the concept of continuum, and by using special elements it can be used to model discontinuums. In the Phase 2 program package (Rocscience 2010) for primary discontinuity modelling, a zero-thickness interface element (Goodman \& Taylor 1968) is used. Unlike the finite elements group representing a continuum, i.e. a block, this element has no thickness and represents a discontinuum, i.e. discontinuity along which displacement and rotation of blocks can occur. Due to the nodes that connect the finite elements, it is not possible to completely separate the blocks.

In order to simulate the behavior of the rock mass, it is necessary to determine the characteristics of the blocks, discontinuity and discontinuity system. Hoek-Brown's (Hoek et al. 2002) failure criterion can be assigned to the blocks (group of finite elements). Properties of stiffness, strength and failure criterion are attributed to the discontinuities (Barton \& Bandis 1990). Stiffness depends on the size of the contact surface, distribution and orientation of the micro fractures and properties of the material between the discontinuities, i.e. infilling. Strength depends on friction along the discontinuity and cohesion caused by the irregularities on the contact surface and the strength of the infilling. Mutually independent stiffness and strength parameters are defined by: normal discontinuity stiffness $(k n)$, shear discontinuity stiffness $(k s)$, and shear 
discontinuity strength formed by cohesion and friction angle $(\phi)$. Discontinuity system (network) is defined by the position, raster, length and discontinuity orientation based on the $E G$ mapping of the cut. If the mapping data is not available for the in itial model, the discontinuity network is approximated and generated based on the borehole determination. In this case, the discontinuity network was obtained by the statistical distribution theories.

The DEM method can directly simulate a complete separation of blocks, cracking of the intact rock, and crushing of the surface discontinuity irregularities. Discrete rock mass behavior and solving real engineering problems (slope and tunnel stability) are modeled using the program packages such as PFC (Itasca 2014). In this program, a parallel bond contact model (Potyondy \& Cundall 2004) is used for modelling the intact rock (cemented and compact grain material), whereas discontinuities are modeled by introducing a smoothjoint contact model (Mas et al. 2008). The modelling procedure is designed in such a way that the intact rock is divided to separate blocks, depending on the position of the discontinuities. The block represents a group of solid grains joined by binder, and the discontinuity is represented by identifying and replacing the contact between the grains along the line, discontinuity surface.

\section{UNDERLYING ASSUMPTIONS}

Rock mass modelling procedure using special elements that represent discontinuities is based on the following assumptions:

Discontinuities in the rock mass of the vertical cuts with large vertical loads behind the slope face have a key role and they determine the behavior of the cut; Primary discontinuities by which a displacement was made, i.e. discontinuities activated during the excavation the impact of which is recorded on the measuring equipment, are modeled; The shear strength of the discontinuity is described using a friction angle. Cohesion was not taken into account because it is a surface excavation (small pressures), as suggested by Goodman et. al (1968); During the excavation, the input stiffness and strength parameters of the discontinuities are reduced/increased, and the reason is the redistribution of the stresses and force input into the rock mass through cable anchors. The discontinuity parameter values are variable; For faults that are oriented from the construction pit to the cut, there is a pair of theirs that is oriented from the cut to the construction pit $\left(180^{\circ}\right.$ orientation difference) of the same slope (conjugated faults); EG blocks represent an intact rock with fracture systems that do not cause sliding but reduce the modulus of elasticity. Because of this, the empirically determined rock mass modulus was used rather than the modulus of the intact rock. The values of the $E G$ block parameters are invariable; The generally accepted acquisition of rock mass modulus of elasticity using the empirical methods associated with field classifications is not suitable for the karst region; and The influence of water is neglected because of the large porosity of the fractures and the appearance of the caverns (characteristics of the epikarst), as well as creating soakaways while protecting the slope with a shotcrete and grillage construction.

Calibration procedure for the discontinuities parameters During the excavation of the construction pit, it was possible to isolate fault zones, faults and caverns as separate units. Defining a fault is more difficult because they change direction and inclination and are interrupted by other faults. Faults appear as conjugated pairs of normal faults in the extensional stress field.

In the available literature there are no examples of determining discontinuity properties (karst region, limestone) needed for the numerical model. In order to determine discontinuity parameters, calibration of the model, i.e. parametric analysis was performed. The analysis was carried out on the basis of the measurement and observation results and $E G$ mapping for three numerical models, i.e. CPS of the northern slope. On the northern $83 \mathrm{~m}$ long slope, the influence of discontinuity is dominant.

The analysis of the $C P 3$ profile was singled out, which represents the central part of the construction pit above which there is a residential building. Largest deformations, impact of the time-dependent deformations and wedge sliding of the rock mass blocks were recorded on the profile in question.

Graphical representation of the model is given in Figure 3.

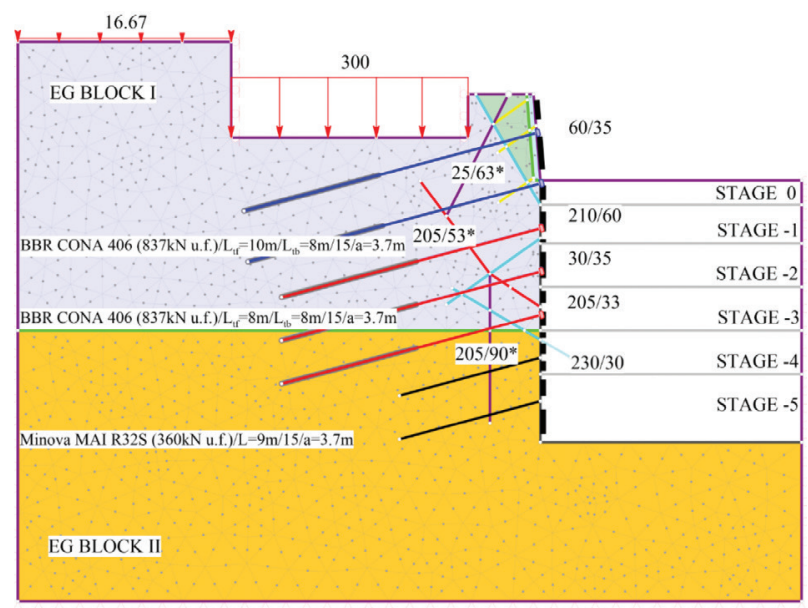

FIGURE 3. View of the numerical model $C P 3$

Classification data, the altitude range of the $E G$ blocks, the points range and the selected $R M R$ classification values for the macro location (five meters to the left and to the right of the profile), and $R Q D$ obtained by coring and determination during the installation of the VI are presented in Table 4. 
TABLE 4. RMR classification data for the northern slope $C P 3$

\begin{tabular}{ccccc}
\hline$E G$ block & altitudes & rock mass point range & joints point range & note \\
\hline 0 & $/$ & $/$ & $/$ & fill behind the wall \\
I & $23.5-9.9$ m a.s.1. & $40-47(40)$ & $7-14$ & $R Q D V I 3 \approx 10 \%$ \\
II & $9.9-$ m a.s.l. & $50-57(56)$ & $7-12$ & $/$ \\
\hline
\end{tabular}

Calibration of the $C P 3$ model was performed on the basis of measuring equipment $(V B, H D 31, H D 32)$ and the results of the $E G$ mapping that indicate the spatial position of the discontinuity in the rock mass (Figure 4). The time taken to analyze the data and calibrate the numeric model is connected with the excavation duration and the construction of the construction pit, which is one year and six months.

The aim of the calibration was to determine a realistic increment of deformation for a timely implementation of the contingency measures (stressing the cable anchors, installing additional ground anchors, backfilling) to stop the progressive failure of the rock mass if needed. Calibration refers to the determination of geometric and physicalmechanical properties of discontinuity.

Discontinuities are divided into three groups: bedding planes, conjugated pairs of faults and special discontinuities. The bedding is intermittently expressed and the general direction of the orientation is to the northwest and north $\left(265^{\circ}-30^{\circ}\right)$. Due to the favorable orientation in relation to the northern slope, the bedding does not affect the behavior of the rock mass.
Conjugated pairs of faults that affect the behavior of the rock mass are 25/63* - 210/60, 25/63* - 205/53*, $30 / 35$ - 205/33, 230/30 - 55/55. These faults define the wedge-shaped blocks and are the main cause of the rock mass deformation. Tensional fracture 205/90*, fracture system $60 / 35$ and discontinuity $300 / 10$, which also represents the boundary of the $E G$ blocks, belong to the group of special fracture systems.

The asterisk above the orientation and discontinuity incline represents a discontinuity (marked in green) that is not mapped on the slope face, but detected by the analysis of the measurement equipment results. These discontinuities extend along the northern slope, and their development, i.e. activation, is detected and modeled on other profiles $(C P 2, C P 4)$.

Initial parameters and activation time (stage) of the discontinuity with the rock mass failure mechanism that they cause are presented in Table 5. Initial, approximate stiffness of discontinuity is determined by the trial and error method. Failure criterion (Barton \& Bandis 1990) and $\mathrm{JCS}=20 \mathrm{MPa}$ and $\mathrm{JRC}=10$ values were attributed
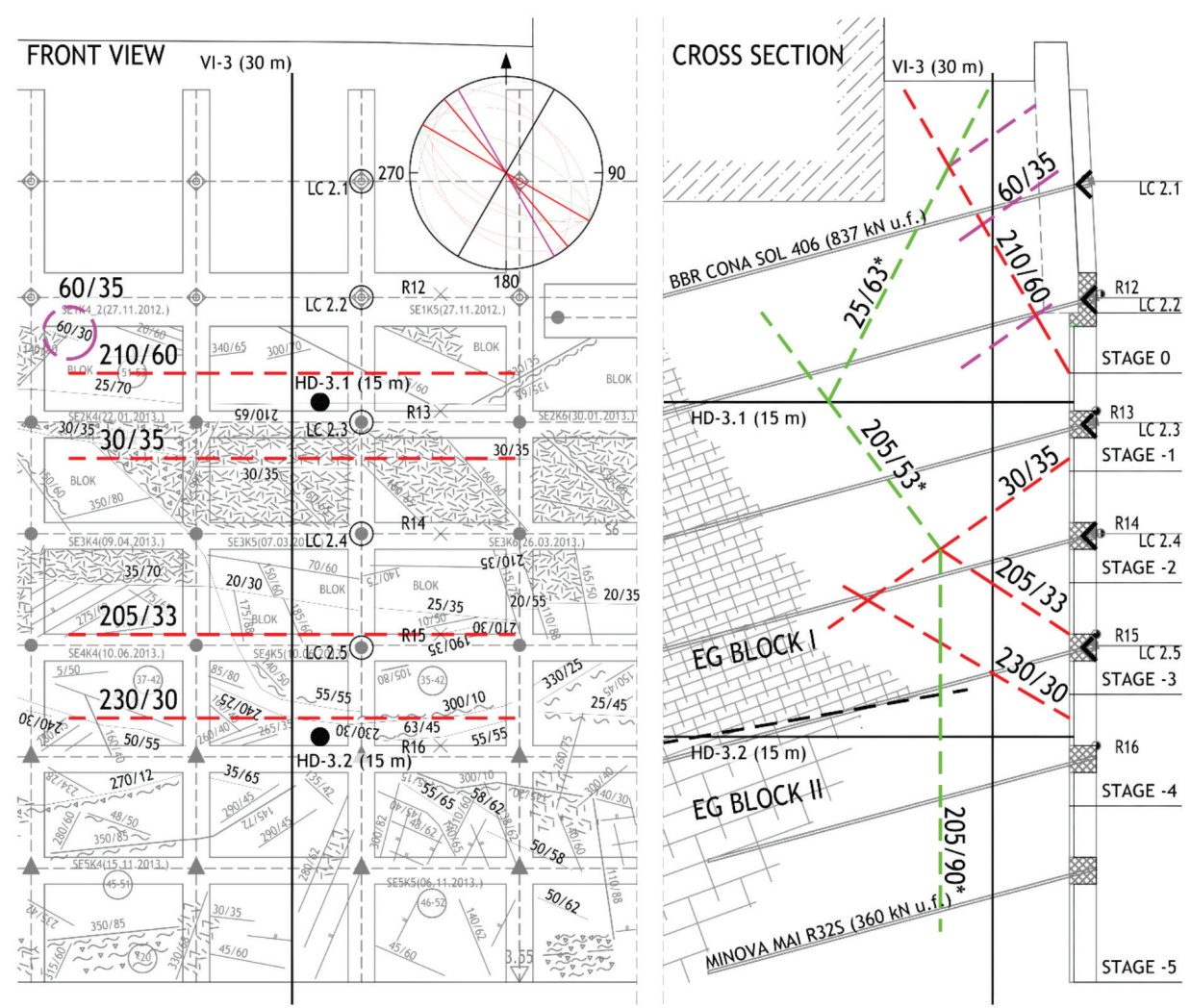

FIGURE 4. View of the northern slope $C P 3$ with the system of discontinuities, structural diagram, measuring equipment and slope protection elements (ground anchors, grillage construction, shotcrete) 
TABLE 5. Initial discontinuity parameters

\begin{tabular}{cclcccl}
\hline joint & activation & failure mechanism & $k n$ & $k s$ & $\phi$ & \multicolumn{1}{c}{ description of joint } \\
\hline $60 / 35$ & stage -1 & toppling & $50 \mathrm{MPa} / \mathrm{m}$ & $500 \mathrm{MPa} / \mathrm{m}$ & $30^{\circ}$ & closed \\
$30 / 35$ & stage -3 & wedge failure & $250 \mathrm{MPa} / \mathrm{m}$ & $100 \mathrm{MPa} / \mathrm{m}$ & $30^{\circ}$ & vertically closed; laterally open \\
$205 / 33$ & stage -3 & wedge failure & $300 \mathrm{MPa} / \mathrm{m}$ & $40 \mathrm{MPa} / \mathrm{m}$ & $32^{\circ}$ & vertically closed; laterally open \\
$230 / 30$ & stage -3 & complex failure & $40 \mathrm{MPa} / \mathrm{m}$ & $100 \mathrm{MPa} / \mathrm{m}$ & $32^{\circ}$ & open; infilling \\
$205 / 53^{*}$ & stage -4 & complex failure & $500 \mathrm{MPa} / \mathrm{m}$ & $200 \mathrm{MPa} / \mathrm{m}$ & $16^{\circ}$ & closed; weared \\
$210 / 60$ & stage -4 & planar failure & $170 \mathrm{MPa} / \mathrm{m}$ & $70 \mathrm{MPa} / \mathrm{m}$ & $40^{\circ}$ & open; infilling \\
$25 / 63^{*}$ & stage -4 & toppling & $500 \mathrm{MPa} / \mathrm{m}$ & $40 \mathrm{MPa} / \mathrm{m}$ & $/$ & vertically open; laterally closed \\
$205 / 90^{*}$ & stage -5 & toppling & $500 \mathrm{MPa} / \mathrm{m}$ & $40 \mathrm{MPa} / \mathrm{m}$ & $/$ & closed \\
\hline
\end{tabular}

to all discontinuities, with the exception of discontinuity 25/63* and 205/90*, which behave as tensional fracture.

Reduction of discontinuity strength and change of discontinuity stiffness is caused by the interventions on the rock mass, e.g. excavation, ground anchor installation, support structure construction, and it is shown in Table 6 . The model is calibrated in such a way that the initial discontinuity parameters (given in the previous table) are multiplied by coefficient $F$ dependent on the excavation procedures, measurement results, position, inclination and length of discontinuity and $P D C$ (project design change).

\section{Discussion ON THE NuMERICAL MODEL RESUltS}

Of the total of five profiles, the influence of discontinuity on the rock mass behavior is dominant on the northern slope. The length of the northern $C P$ is about $25 \mathrm{~m}$ and the activated discontinuities are situated in a $7 \mathrm{~m}$ thick layer from the slope face. Due to the proximity of the $C P \mathrm{~s}$, their comparison gives a three-dimensional cut model. The $C P 3$ represents the central part of the northern slope above which there is a residential building.

Based on the measurement results, calibrated $C P 3$ model and defined threshold, intervention was carried out in the initial design solution on 13 June 2013, i.e. contingency measures were activated after the excavation of stage -4 (Figure 5(a)). The intervention was carried out in such a way that three rows of cable anchors (15 pieces) were further stressed at a force of $350 \mathrm{kN}$ (the force before the stressing was about $250 \mathrm{kN}$ ), which stabilized the cut, and the impact of the excavation on the residential building was reduced to a minimum (Savi 2014).

Displacements recorded on $V I 2$ (right side of the northern slope) and VI4 (left side of the northern slope)

TABLE 6. Values of joints parameters depending on the excavation altitude and the cut protection elements

\begin{tabular}{|c|c|c|c|c|c|}
\hline stage & joint & $F k n$ & $F k s$ & $F \phi$ & comment \\
\hline I II III & all & 1 & 1 & 1 & $\begin{array}{l}\text { input values of the parameters have not been changed for the first three } \\
\text { stages, discontinuities were activated depending on the excavation } \\
\text { altitude }\end{array}$ \\
\hline \multirow{2}{*}{ IV } & $230 / 30$ & 1 & 1 & 0.40 & $\begin{array}{l}\text { excavation of stage } 4 \text { resulted in a redistribution of the load and reduction } \\
\text { of the discontinuity strength }\end{array}$ \\
\hline & $30 / 35$ & 0.20 & 0.20 & 1 & $\begin{array}{l}\text { change represents the separation of the wedge and the redistribution of } \\
\text { the load near the slope face - the belly of the cut }\end{array}$ \\
\hline \multirow{6}{*}{ 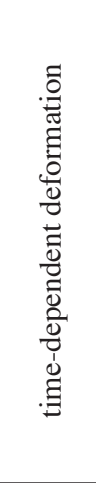 } & $60 / 35$ & 1 & 1 & 0.50 & $\begin{array}{l}\text { change is dependent on the activation time, stiffness and strength of } \\
\text { other discontinuities }\end{array}$ \\
\hline & $205 / 33$ & 1 & 1 & 0.20 & \multirow{2}{*}{$\begin{array}{l}\text { redistribution of the load develops a sliding surface with a serial activation } \\
\text { of two discontinuities from the slope face towards the foundation of the } \\
\text { building }\end{array}$} \\
\hline & $205 / 53 *$ & 1 & 1 & 0.60 & \\
\hline & $230 / 30$ & 1 & 1 & 0.22 & $\begin{array}{l}\text { change represents a further decline in the discontinuity strength, i.e. the } \\
\text { effect of the time-dependent deformation }\end{array}$ \\
\hline & $210 / 60$ & 1 & 1 & 0.20 & $\begin{array}{l}P D C \text {, discontinuity was once again activated (visible from } 19 \text { to } 23 \\
\text { ma.s.l.), and the change was modeled by reducing discontinuity strength }\end{array}$ \\
\hline & $30 / 35$ & 0.40 & 0.40 & 1 & $\begin{array}{l}P D C \text {, the rock mass of } 10-15 \mathrm{~m} \text { a.s.l. was reinforced and stiffness of } \\
\text { discontinuity was increased }\end{array}$ \\
\hline \multirow[b]{2}{*}{$\mathrm{V}$} & $230 / 30$ & 1 & 1 & 0.19 & significant time-dependent deformations were stopped. \\
\hline & $60 / 35$ & 1 & 1 & 0.40 & $\begin{array}{l}\text { change is dependent on the activation time, stiffness and strength of } \\
\text { other discontinuities }\end{array}$ \\
\hline
\end{tabular}


are within the expected values and are approximately twice as small as the central VI3 (Figure 5(b)). The measuring equipment $V I 4, H D 41, H D 42$ determined a tensional fracture 205/90* which became activated between 06 September 2013 and 20 September 2013 in the background of the slope face, and stretches along the entire northern slope. This fracture caused increased deformation at the top of the slope.

Stabilization of the cut deformation and forces in the cable anchors occurred slower on the measuring equipment associated with the $C P 3$ than in the other $C P$ s due to time-dependent deformations. Therefore, Figure 6 shows the displacement/time relationship (line) during the excavation of stage -5 for four height-characteristic points. It can be seen from the line slope that the displacement stopped and a balanced, stable state of strengthened rock mass was achieved since 09 January 2014.

Within the FEM framework stability analysis of CP3 model was performed using the Shear Strength Reduction technique (Hammah et al. 2008). The results of the analysis show a SRF (Shear Reduction Factor) of 4.5 with the effect of discontinuity and 8.9 without modelling discontinuity. By observing the development of deformation, stress and appearance of yielding areas, it is possible to recognize the most heavily loaded discontinuum 230/30. The discontinuity in question is responsible for the beginning of the development of excessive displacements.

\section{CONCLUSION}

The basic idea of rock mass modelling is the separation of the influence of the intact rock/IG blocks (intact rock disrupted by a fracture system without the possibility of slip) from dominant discontinuities. There are two ways of modelling the rock mass: Indirect (finite element method using special elements, Goodman's joint element) and direct (discrete element method), depending on the way of defining the damage. Determination of discontinuity parameters with field-based procedures, which depend on the field situation, is a challenging task. When it comes to
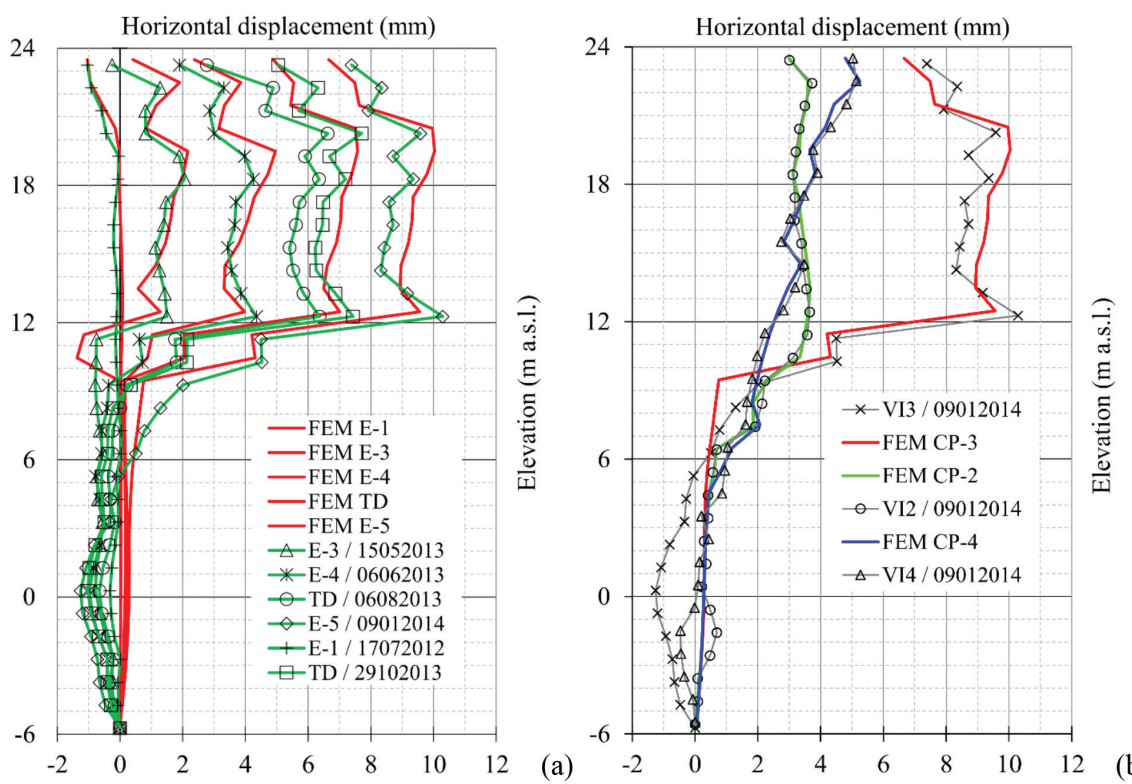

FIGURE 5. Comparison of measurement and model results: (a) increment of deformation $C P 3$ - VI3 (b) the final displacements $C P 2-V I 2, C P 3-V I 3, C P 4-V I 4$

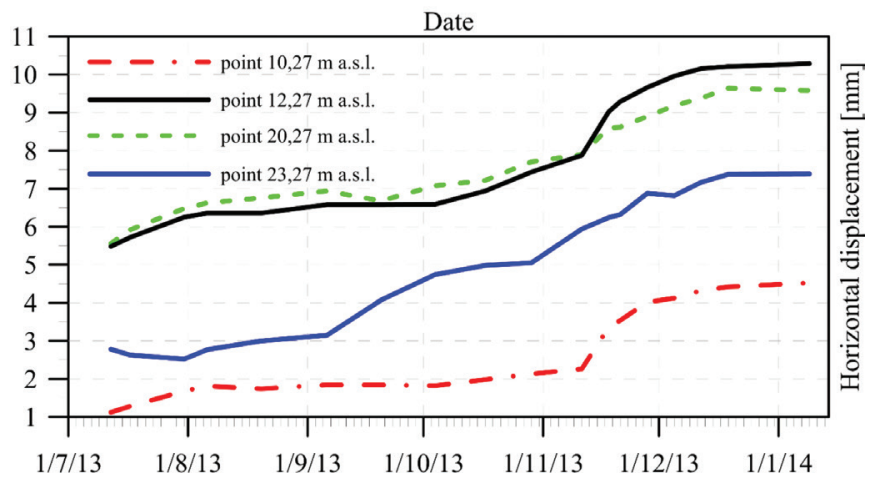

FIGURE 6. The displacement/time relationship during the excavation of stage -5 
karst, description procedures of discontinuity properties in karst region, necessary for numerical analysis, are rare in literature. First, it is necessary to determine the position, orientation and inclination of activated discontinuities based on engineering-geological mapping and analysis of the measurement results. After determining the initial discontinuity parameters, the strength reduction coefficient and discontinuity stiffness should be defined. Reduction (it can also be an increase) is caused by the interventions performed on the rock mass (excavation, stressing of the cable anchors, construction of the supporting structure) and time-dependent deformations.

This paper gives an example of the simulation of excavation of the Zagrad B construction pit with the dominant influence of discontinuity on the behavior of the rock mass cut. Based on the rock mass classification, two engineering-geological blocks were isolated and strength criterion and modulus of elasticity (adapted to karst) were attributed to them. Discontinuity properties are determined by means of parametric analysis using a numeric model, as well as through calibration by using measurement and observations results. With successful modelling of discontinuities, it is possible to obtain realistic increments of deformation (deformation after removing a smaller rock mass volume) and determine the threshold for the activation of contingency measures. If the measured displacements are greater than the threshold (numerically defined), contingency measures are activated (stressing the cable anchors, installing additional ground anchors, backfilling). Through this procedure, timely interventions were carried out in the initial design solution of the Zagrad B construction pit.

Rock mass modelling using the discrete element method is a logical continuation of the study of the influence of discontinuity in the rock mass. By comparing the micro (discrete element method) and macro (finite element method) discontinuity parameters, it is possible to link laboratory and field measurements and explore the behavior of a complex dynamic system, i.e. rock mass.

\section{REFERENCES}

Arbanas, Z. 2003. Construction of Zagrad foundation pit in Rijeka. Građevinar 55: 591-597.

Barton, N.R. \& Bandis, S. 1990. Review of predictive capabilities of JRC-JCS model in engineering practice. Proc. Int. Symp. on Rock Joints, Rotterdam: Balkema, pp. 603-610.

Bieniawski, Z.T. 1989. Engineering Rock Mass Classifications. New York: Wiley.

Bjureland, W., Spross, J., Johansson, F., Prästings, A. \& Larsson, S. 2017. Reliability aspects of rock tunnel design with the observational method. International Journal of Rock Mechanics \& Mining Sciences 98: 102-110. https://doi. org/10.1016/j.ijrmms.2017.07.004.

Bonilla-Sierra, V., Scholtes, L., Donze, F.V. \& Elmouttie, M. 2015. Rock slope stability analysis using photogrammetric data and DFN-DEM modelling. Acta Geotechnica 10(4): 497-511. https://doi.org/10.1007/s11440-015-0374-z.
Chen, S., Goh, T.L., Han, L. \& Tovele, G.S.V. 2019. Effects of tectonic stresses and structural planes on slope deformation and stability at the Buzhaoba Open Pit Mine, China. Sains Malaysiana 48(2): 317-324. https://doi.org/10.17576/jsm2019-4802-07.

Frka, R. 2014. Digital Photography: Zagrad B2, B6. Rijeka.

Goodman, R.E. \& Taylor, L.R. 1968. A model for the mechanics of jointed rock. Journal of the Soil Mechanics and Foundations Division, Proceedings of ASCE 94(SM3): 636-659.

Hammah, R.E., Yacoub, T.E., Corkum, B.C. \& Curran, J.H. 2008. The practical modelling of discontinuous rock masses whit finite element analysis. The 42nd U.S. Rock Mechanics Symposium (USRMS), 29 June-2 July, San Francisco, California. American Rock Mechanics Association.

He, Y., Peng, S., Du, W., Tang, X. \& Zeng, H. 2017. Laboratory study of acoustic velocity in different types of rocks at seismic frequency band. Sains Malaysiana 46(11): 2187-2193. http:// dx.doi.org/10.17576/jsm-2017-4611-20.

Hoek, E., Carranza-Torres, C.T. \& Corkum, B. 2002. HoekBrown failure criterion-2002 edition. In Proceedings of the Fifth North American Rock Mechanics Symposium 1: 267-273.

Hoek, E. \& Diederichs, M.S. 2006. Empirical estimation of rock mass modulus. International Journal of Rock Mechanics and Mining Sciences 43: 203-215. https://doi.org/10.1016/j. ijrmms.2005.06.005.

Huang, L., Xu, Z. \& Zhou, C. 2009. Modeling and monitoring in a soft argillaceous shale tunnel. Acta Geotechnica 4: 273-282. https://doi.org/10.1007/s11440-009-0100-9.

Itasca. 2014. PFC Version 5.0 documentation.

Jing, L. \& Hudson, J.A. 2002. Numerical methods in rock mechanics. International Journal of Rock Mechanics and Mining Sciences 39(4): 409-427. https://doi.org/10.1016/ S1365-1609(02)00065-5.

Jurić Kaćunić, D., Arapov, I. \& Kovačević, M.S. 2011. New approach to the determination of stiffness of carbonate rocks in Croatian karst. Građevinar 63(2): 177-185.

Kujundzic, B. \& Grujic, N. 1966. Correlation between static and dynamic investigations of rock mass "in situ". Proc. of 1st ISRM Congress 1: 565-570.

Latha, G.M. \& Garaga, A. 2012. Elasto-plastic analysis of jointed rocks using discrete continuum and equivalent continuum approaches. International Journal of Rock Mechanics \& Mining Sciences 53: 56-63. https://doi.org/10.1016/j. ijrmms.2012.03.013.

Lin, J.S. \& Ku, C.Y. 2006. Two-scale modeling of jointed rockmasses. Int. Jour. Rock Mech. Min. Sci. 43: 426-436. https://doi.org/10.1016/j.ijrmms.2005.07.009.

Louie, J.N. 2001. Faster, Better: Shear-wave velocity to 100 meters depth from refraction microtremor arrays. Bulletin of the Seismological Society of America 91(2): 347-364.

Mohd Razib, A.M., Goh, T.L.., Mazlan, N.A., Fahmi Abdul Ghani, M., Tuan Rusli, T.M., Ghani Rafek, A., Serasa, A.S., Chen, Y. \& Zhang, M. 2018. A systematic approach of rock slope stability assessment: A case study at Gunung Kandu, Gopeng, Perak, Malaysia. Sains Malaysiana 47(7): 14131421. http://dx.doi.org/10.17576/jsm-2018-4707-08.

Marinos, P. \& Hoek, E. 2000. GSI - a geologically friendly tool for rock mass strength estimation. Proc. GeoEng2000.

Mas, I.D., Potyondy, D.O., Pierce, M. \& Cundall, P.A. 2008. The smooth-joint contact model. 8th. World Congress 
on Computational Mechanics (WCCM8), 5th. European Congress on Computational Methods in Applied Sciences and Engineering (ECCOMAS 2008).

Pavlic, V. 2014. Residential-Business Complex with Underground Garage "Zagrad B". Rijeka Projekt. Implementation geotechnical design: Construction pit protection design (stress-deformation analysis), 3300-666-2010/2, Institute IGH JSC.

Pollak, D. 2007. Influence of carbonate rock masses on their engineering-geological properties. Ph.D. thesis, Faculty of Mining, Geology and Petroleum Engineering, University of Zagreb, Zagreb (Unpublished).

Potyondy, D.O. \& Cundall, P.A. 2004. A bonded-particle model for rock. International Journal of Rock Mechanics and Mining Sciences 41: 1329-1364. https://doi.org/10.1016/j. ijrmms.2004.09.011.

Rocscience Inc. 2010. Phase2 V7.0 - A Two-Dimensional Finite Element Analysis Program.

Savi, R. 2014. Residential-Business Complex with Underground Garage "Zagrad B". Rijeka Projekt. Measurement and testing report, 2130-T-001/14, Institute IGH JSC.

Shen, C.K., Sadigh, K. \& Herrmann, L.R. 1978. An analysis of NGI simple shear apparatus for cyclic soil testing. Dynamic Geotechnical Testing, ASTM STP 654. pp. 148-162.

Sturzeneger, M., Stead, D. \& Pavicic, K. 2009. Close-range terrestrial digital photogrammetry and terrestrial laser scanning for discontinuity characterization on rock cuts. Engineering Geology 106(3-4): 163-182. https://doi. org/10.1016/j.enggeo.2009.03.004.
Tang, S.B., Huang, R.Q., Tang, C.A., Liang, Z.Z. \& Heap, M.J. 2017. The failure processes analysis of rock slope using numerical modelling techniques. Engineering Failure Analysis 79: 999-1016. https://doi.org/10.1016/j. engfailanal.2017.06.029.

Tomac, V. 2012. Residential-Business Complex with Underground Garage "Zagrad B". Rijeka Projekt. Graund anchor assessment tests report, BBR Adria Ltd.

Vuic, V.G., Opacak, G. \& Pavicic, K. 2014. Residential-business complex with underground garage "Zagrad B". Rijeka Projekt. Engineering Geological Mapping Report, 4300-3/14, Institute IGH JSC.

Vedran Pavlic

Hidroinzenjering d.o.o.

Okucanska 30, 10000 Zagreb

Croatia

Mario Bacic* \& Meho Sasa Kovacevic

University of Zagreb, Faculty of Civil Engineering

Kaciceva 26, 10000 Zagreb

Croatia

*Corresponding author; email: mbacic@grad.hr

Received: 10 April 2019

Accepted: 17 September 2019 